\title{
THE ROLE OF TOURISM DEPARTMENT AND REGIONAL TOURISM PROMOTION AGENCY IN DEVELOPING COMMUNITY BASED TOURISM
}

\author{
Ni Ketut Bagiastuti, SH., M.H. \\ Tourism Department \\ Bali State Polytechnic \\ Badung, Indonesia \\ utie_72mrt@yahoo.com
}

\author{
Ni Nyoman Sri Astuti, STT.Par., M.Par \\ Tourism Department \\ Bali State Polytechnic \\ Badung, Indonesia \\ merryoming@yahoo.com
}

Abstract- The main task of tourism department according to the regulation of Bali Governor no 51 of 2008 is to formulate technical policies in the field of tourism, to manage and facilitate the field of tourism, to issue licenses and to carry out public services in the field of tourism, fostering the implementation of tasks in the field of tourism and to carry out administrative affairs. In line with the importance of tourism and to develop tourism in order to achieve social welfare, then, the regional government has established an agency to promote Tourism in Indonesia. The establishment of a regional tourism agency is based on act no 10 of 2009 regarding tourism, where this agency is an independent private agency. This agency becomes partner for regional government to promote tourism sector. Nowadays, tourism sector in Indonesia is not only focused on profit oriented, but it is more about improving community welfare. Thus, community based tourism concept is the most appropriate concept to be implemented in order to achieve the goal. One form ofhas 11 (eleven) tourist villages, and eight of them are not improved yet due to the role of the tourism department which has not been maximized yet. The Regional Tourism Department is not only as a policy maker, but it also has a role to conduct supervision and guidance toward the tourist villages by requesting advice from Regional Tourism Promotion Agency. This agency has the main task to promote tourism including tourist villages, thus, automatically this agency knows more the need of tourism market. Such as; giving appropriate education to the human resources, reviewing management system and improving existed tourist destination, facilities and infrastructure. The Regional Tourism Promotion Agency as an implementer agency a has role to submit advices to the Regional Tourism Department and also to guide the tourist village development. Beside the mutual cooperation between the partners, community role is also important. Community as the manager of tourist village, must be able to coordinate actively with the Regional Tourism Department and Regional Tourism Promotion Agency, therefore, the eight tourist villages which are not developed well yet can be saved. The Regional Government must put attention on it. There must be a synergistic relationship between the Regional Tourism Department, The Regional Tourism Promotion Agency and the Tourist Village so that Tourist Village as one form of Community Based Tourism can be developed according to its goal.

Keywords - Regional Tourism Department, Regional Tourism Promotion Agency, Community Based Tourism

\section{INTRODUCTION}

"Tourism is the sum of operations, mainly of an economic nature, which directly related to the entry, stay and movement of foreigner inside certain country, city or region". (Schulalard ; 1910 in A. Yoeti) ${ }^{1}$. Based on his opinion, what is meant by tourism is number of activities, especially those are related to economic activities which are directly related to the arrival, staying and moving in or out foreigner to a town, region and country.

Act nu 10 of 2009 chapter I Section 1 Subsection 3 stated that tourism is a wide range tourist activities supported by vary facilities and also services which is provided by community, company, government and regional government. Tourism covers 3 (three) components, they are tour, attraction management and tourist attraction, and also other economic activities outside that field but still related with tourism. (Directorate General of Tourism, 1985) ${ }^{2}$. In globalization era nowadays, tourism sector has become one of biggest and most powerful industry in world, and tourism is the biggest revenue sector especially in community economic life and country. Tourism activities have become part of community life from community who lives in a city until community who lives in a village (Adirozal, Zulkarnain Harun, Year IV Nu 6 July December 2002) ${ }^{3}$. In community, especially those who are concern to economic improvement in their village or those who are willing to improve their family ecomonic life will realize the importance role of tourism in order to generate their income. These tourism activities carried out by these communities are aimed to promote the progress of local economic development. This condition will also affected to the increasing of economic development in a country because the improvement of its regional economic development. Thus, the burden which borne by the state will be reduced because its regional actively participated in developing their economic. This proves that the role of tourism in developing economy of

${ }^{1}$ Yoeti, A, Oka, Pengantar Ilmu Pariwisata, 1996, Angkasa Bandung, Cetakan Pertama, hal 105

2 Ditjen Pariwisata, 1985, Pengantar Pariwisata Indonesia, Jakarta, Direktorat Jendral Pariwisata, hal 3

${ }^{3}$ Adirozal, Zulkarnain Harun Jurnal Antropologi, Tahun IV No 6, Juli-Desember 2002 
a society or a country is enormous. In the other hand, tourism is not only about economic development, but it is also related to social, cultural, politics development and so on. This is in line with argumentation from I Gde Pitana who stated that tourism is a multicomplex system with a various aspects which is interrelated and influenced among each other (Pitana, I Gde \& Putu G Gayatri. 2005) ${ }^{4}$. A tourism sociology. Andi: Yogyakarta). In line with that, an agency that specifically focus on tourism issues is required.

In government structure of Badung Regency, Tourism Department has main task in tourism sectors in general such as; set up plan, operational policy, control and organize activities related to tourism which cover administration, tourist facilities, site and tourist attraction, promotion and marketing. (Anonim.2012) ${ }^{5}$. Beside Tourism Department, based on Act No. 10 of 2009 regarding tourism, Government can also establish an agency which is in charge of promoting tourism; Regional Tourism Promotion Agency. It is stated that "Government can facilitate the establishment of Regional Tourism Promotion Agency based in capital city of province and in regency/city". "The Regional Tourism Promotion Agency is an independent private agency". Regional Tourism Promotion Agency is aimed to improve the image of tourism in Indonesia, to increase the number of foreign tourist's arrival and foreign exchange earnings, local tourist arrival, and expenditure. Regional Tourism Promotion Agency also has role as tourism promotion coordinator which is carried ou by private sectors in central and regional and also as a partner of government and regional government. As partner, this agency must be able to create a conducive and comfortable environment so that every actors of cultural and tourism activities can develop effectively and efficiently.

Based on the vision of Badung Tourism Department that states "to establish a qualified, eco-friendly and cultural minded development and also wider community involvement". (Anonim. 2012) ${ }^{6}$. Thus, in terms of developing tourism potential in Badung Regency is not only depend on government effort but community involvement and participation is also required. The success of tourism is not only measured by the number of foreign tourist arrival but it is more about developing and expanding community potential economic opportunity that can attract tourist to come. Simply, participation is a process where community as stakeholders can actively involve to influence and control development in their own place. Community participate actively in initiating their lifes through a process of decision making and access to resources and its management. To date, the development tourism which is based on community has used the community based tourism as an approach, where communities play an important role in improving tourism development. In Bali, one of implementing model of community based tourism is tourist

\footnotetext{
${ }^{4}$ Pitana, I Gde \& Putu G Gayatri. 2005. Sosiologi Pariwisata. Andi: Yogyakarta, hal 23

${ }^{5}$ Anonim.2012, Profil Dinas Pariwisata Kabupaten Badung Tahun 2012, Badung, Pusat PemerintahanMangupraja, hal 10

${ }^{6}$ Anonim.2012.....ibid
}

village. In Badung Regency, there are 11 (eleven) tourist village. This tourist village is established to improve local community welfare through a community based tourism development. However, the implementation of the community based tourism in Badung Regency through tourism village is not running optimally. Meanwhile, the one that is in charge regarding success or failure of tourism development in a region is ofcourse Regional Tourism Department. In line with that, it is necessary to identify how Regional Tourism Department and Regional Tourism Promotion Agency implement their role in order to succeed community based tourism concept

\section{METHODOLOGY}

According to Peter Mahmud Marzuki ${ }^{7}$ legal research is a process to decide rule of law, principles of law, nor doctrines faced. It is in line with the character of legal science perspective. The type of research in study on role of Badung Regency Regional Tourism Department and Regional Tourism Promotion Agency in developing community based tourism is included in judicial empirical research, a research conducted by directly collecting data in Badung Regency Regional Tourism Department and under the laws in force

Another approach which is used is conceptual approach. In this case, one concept which is used is decentralization concept. In section 1 number 7, Act No. 32 of 2004 on Regional Government stated that decentralization is "Handover government authority from Central Government to regional autonomy to manage and arrange government affairs in the unitary state system of Indonesian Republic." Related to the task, regulation of Bali Governor no 51 of 2008 on main task of Regional Tourism Department is also examined. It states that Regional Tourism Department has main task to carry out part of domestic and regional affairs in the field of tourism. Towards the conceptual approach above, the role of Tourism Department is as a partner of Regional Tourism Promotion Agency to succeed community based tourism. In principle, the tourism organization, in this case is Regional Tourism Department is a department that directly in charge in terms of formulating tourism policy within national scope. (Bagyono, 2005) ${ }^{8}$. Therefore, tourism organization (Disprada) also has a task to carry out supervision and giving direction in developing tourism sectors ${ }^{9}$.

The next concept which is used is tourist village concept. Tourist village is "A rural area which offers a whole atmosphere that reflects the authenticity of the countryside

\footnotetext{
7 Amiruddin dan Zainal Asikin, 2004, Pengantar Metode Penelitian Hukum, PT. Raja Grafindo Persada, Jakarta, hal 118

${ }^{8}$ Bagyono, 2005, Pariwisata dan Perhotelan, Alfabeta, Bandung, hal 29

${ }^{9}$ Ni Ketut Bagiastuti, 2011, Wewenang Pemerintah Daerah Dalam Pembentukan Badan Promosi Pariwisata Daerah Provinsi Bali, Tesis, Udayana, Bali
} 
both in social and economic life, social culture, customs, daily life, has the architecture and structure of the village spatial characteristic, or economic activities which are unique and interesting and has the potential for development of various tourism components, such as: attractions, accommodation, food and beverage, souvenirs, and other travel needs

Other concept that is used in this research is Community Based Tourism Concept. Conceptually, the basic principle of community based tourism is to address the community as the main actors through community empowerment in various tourism activities, so that the maximum benefit of tourism is for the community. The main target of tourism development must be aimed to improve the welfare of the community (local). The concept of community based tourism development is usually used by designers of tourism development strategy in order to mobilize the community to actively participate in developing tourism as partners of tourism industry. Tourism based on community is as an approach of empowerment which involving and addressing community as significant actors in the context of new development paradigm, a sustainable development paradigm.

\section{RESULT AND DISCUSSION}

Definition of Community Based Tourism is a tourism concept that aware of culture, social and environmental sustainability. This tourism format is managed and owned by community and for the community benefit themselves, in order to help visitor to understand more about the community and their local way of life. Therefore, Community Based Tourism concept is much different from a mass tourism concept. Community Based Tourism is not a tourism business sectors that emphasizes on profit or other interested parties economic sectors profit only, but it is more related to the impact of tourism business sectors to local community and their environmental resources. Community Based Tourism is a tourism development model which assumes that tourism must derived from the community need awareness value as an effort to build a tourism which is more beneficial to the needs, initiatives and opportunities to local community (Hadiwijoyo, Suryo S. 2012) ${ }^{10}$. Community Based Tourism is not a tourism business that is aimed to maximize investors' profit. Community Based Tourism is more related to the impact of tourism sectors for community and environmental resources. Community Based Tourism is born from community development strategy with tourism as its tools to strengthen the organizational capability of local community. One form of Community Based Tourism is tourist village. According to Nuryanti (1993) $)^{11}$, Tourist Village is an integrated form of attraction, accommodation and supporting facilities that is served in a structure of community way of life and blended

${ }^{10}$ Hadiwijoyo, Suryo S. 2012. Perencanaan Pariwisata Perdesaan Berbasis Masyarakat; Sebuah Pendekatan Konsep,Yogyakarta :Graha Ilmu. Hal 71

${ }^{11}$ Ni Nyoman Ayu Hari Nalayani, 2012, Evaluasi Dan Stategi Pengembangan Desa Wisata Di Kabupaten Badung, Bali,Tesis, Universitas Udayana with existed community custom and tradition. In this frame, we can see the significant role of local community in order to establish an integrated tourist attraction. The implementation of Regional Autonomy requires Regional Government becomes facilitator for developing and constructing tourism object based on Community Based Tourism concept.

Badung Regional Tourism Department in order to develop tourism sectors in their territories has already planned and conducted the concept above through Badung Regent Regulation no 47 of 2010 on establishment of tourist village in Badung territory. Based on Ni Nyoman Ayu Hari Nalayani research since 2010, Badung Regency already has 11 tourist village located in North Badung and Middle Badung, they are; (1) Banjar Karang Dalem I, Bongkasa Pertiwi Village, Abiansemal sub district; (2) Sangeh Village, Abiansemal sub district; (3) Banjar Sekar Mukti Pundung, Pangsan Village, Petang sub district; (4) Banjar Kerta, Petang Village, Petang sub district; (5) Banjar Kiadan, Pelaga Village, Petang sub district; (6) Banjar Lawak, Belok village, Petang sub district; (7) Carang Sari Village, Petang sub district; (8) Baha Village, Mengwi sub district; (9) Kapal Village, Mengwi sub district; (10) Mengwi Village, Mengwi sub district; dan (11) Munggu village, Mengwi sub district. These eleventh tourist village have been defined by Regent Letter of Decree but unfortunately these villages have not been developed based on the Community Tourism Based Concept yet where the community supposed to be the main actors through community development in every tourism activities, so that the maximum benefit from tourism sectors can go to the community ${ }^{12}$.

The existence of tourist village as a form of Community Based Tourism in Badung Regency does not run optimally. Eigth from eleven tourist villages are not developed at all. (Mangupura, Denpost 20/04/2016) ${ }^{13}$. The eight of the tourist villages are rarely to be visited by tourists. This condition of course gives a bad influence to the local economic improvement. This condition is triggered by the role of regional government (Disparda) which has not optimal yet. Below is the pattern that can explain the role of Regional Tourism Department, Regional Tourism Promotion Agency and Tourist Village in order to develop the Community Based Tourism.

\footnotetext{
${ }^{12}$ Nuryanti, Wiendu. 1993. "Concept, Perspective and Challenges". Makalah bagian dari Laporan Konferensi Internasional mengenai Pariwisata Budaya di Yogyakarta

${ }^{13}$ Mangupura, Denpost 20/04/2016
} 
Figure 1. Cooperation figure

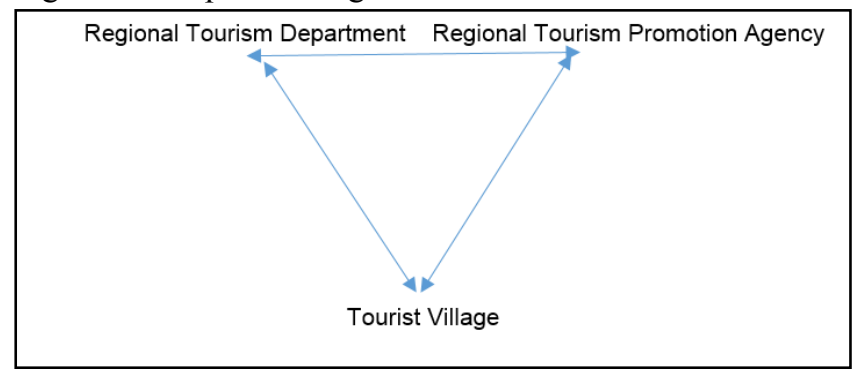

Based on the cooperation figure 1, can be explained that there should be a synergistic relationship between the Regional Tourism Department - Regional Tourism Promotion Agency and Tourist Village. Regional Tourism Department as a policy maker, in this case is in charge to set up a tourist village. In the other hand, as a department that in charge of developing tourism in their territory, Regional Tourism Department is not only in charge of regulation matter. Regional Tourism Department must also conduct their supervision role and establish a direction in terms of tourism development. As a policy maker, Regional Government can not only issued a letter of decree and then let the tourist village run without any further guidance. Regional Tourism Department must provide a proper guidance so that the tourist village can be continuously developed. Regional Tourism Department may request advices from Regional Tourism Promotion Agency. As partner of regional government, this Regional Tourism Promotion Agency has an obligation to submit advices to regional government because this agency knows more about what is needed by the tourism market. Besides that, this agency can also provide guidance to the tourist village based on the need of tourism market. Because this agency that is in charge to promote the tourist village as a form of Community Based Tourism. From the cooperation pattern above, it also can be seen that the success of tourist village is influenced by an active coordination between community as the tourist village manager with Regional Tourist Department and Regional Tourism Promotion Agency including in terms of decision making. Because beside role of regional government, an active community participation will also determine success development of tourist village. A professional management can improve the welfare of community who lives in tourist village.

For the eight tourist villages which is categorized as undeveloped in Badung Regency, Regional Tourism Department must conduct a proper guidance and supervision through education such as; conducting training to the human resources as the manager of tourist village, hotels and existed tourism schools. Regional Government can also conduct monitoring and evaluation to the tourist village management system. And another important thing, Regional Government need to make a correction by improving the facilities and infrastructures of tourist attraction so that the eight tourist village can be developed as good as the three other. A synergistic partners between Regional Tourism Department and Regional Tourism Promotion Agency can be achieved through establish a good partnership with other stakeholders/industries such as ASITA, PHI and other travel agency to schedule a visit to the tourist villages.

\section{CONCLUSIONS AND SUGGESTION}

Regarding the regional autonomy, the task of Regional Government is to conduct the development and construction in tourist village based on Community Based Development concept. Based on the condition of several tourist village which still undeveloped in Badung regency, it is confirmed that the role of Regional Tourism Department is not only as a policy maker but also need to conduct supervision and guidance through education and improving facilities and infrastructures in order to support development of Community Based Tourism concept. In line with that, Regional Tourism Department need to establish a synergistic relationship with Regional Tourism Promotion Agency as a partner. Role of Regional Tourism Promotion Agency as partner for regional government is as the policy implementer beside submitting advice and providing guidance to tourist village by involving other stake holders/industry. Community as the manager of tourist village need to be proactive to coordinate with Regional Tourism Department and Regional Tourism Promotion Agency. Therefore, in order to achieve the sustainability of tourist village as one form of Community Based Tourism, there must be a synergistic relationship between Regional Tourism Department, Regional Tourism Promotion Agency and Tourist Village. In this current situation, Regional Government must focus on conducting their role and give full attention to the undeveloped eight tourist villages before establishing another new tourist village. There must be a facts of integrity from community so that funds that is delivered will not be wasted and the most important thing is to create the tourism development that can support community welfare improvement.

\section{REFERENCES}

[1] Yoeti, A, Oka, Pengantar Ilmu Pariwisata, 1996, Angkasa, Bandung, Cetakan Pertama

[2] Ditjen Pariwisata, 1985, Pengantar Pariwisata Indonesia, Jakarta, Direktorat Jendral Pariwisata,

[3] Adirozal, Zulkarnain Harun Jurnal Antropologi, Tahun IV No 6, JuliDesember 2002

[4] Pitana, I Gde \& Putu G Gayatri. 2005. Sosiologi Pariwisata. Andi: Yogyakarta

[5] Anonim.2012, Profil Dinas Pariwisata Kabupaten Badung Tahun 2012, Badung, Pusat PemerintahanMangupraja

[6] Amiruddin dan Zainal Asikin, 2004, Pengantar Metode Penelitian Hukum, PT. Raja Grafindo Persada, Jakarta.

[7] Bagyono, 2005, Pariwisata dan Perhotelan, Alfabeta, Bandung

[8] Ni Ketut Bagiastuti, 2011, Wewenang Pemerintah Daerah Dalam Pembentukan Badan Promosi Pariwisata Daerah Provinsi Bali, Tesis, Udayana, Bali

[9] Hadiwijoyo, Suryo S. 2012. Perencanaan Pariwisata Perdesaan Berbasis Masyarakat; Sebuah Pendekatan Konsep,Yogyakarta :Graha Ilmu. 
Figure 1. Cooperation figure

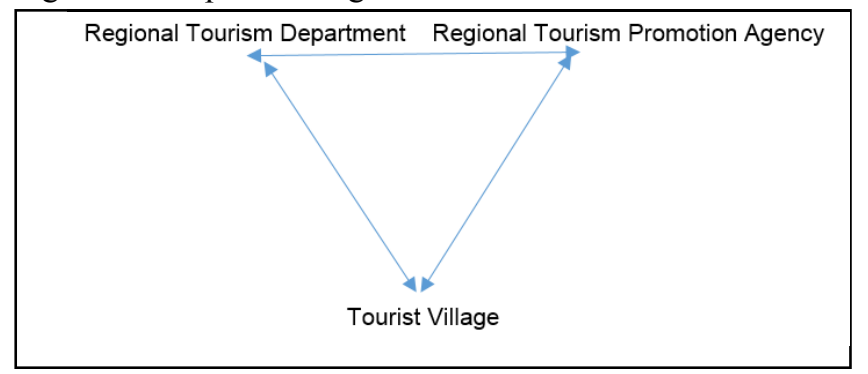

Based on the cooperation figure 1, can be explained that there should be a synergistic relationship between the Regional Tourism Department - Regional Tourism Promotion Agency and Tourist Village. Regional Tourism Department as a policy maker, in this case is in charge to set up a tourist village. In the other hand, as a department that in charge of developing tourism in their territory, Regional Tourism Department is not only in charge of regulation matter. Regional Tourism Department must also conduct their supervision role and establish a direction in terms of tourism development. As a policy maker, Regional Government can not only issued a letter of decree and then let the tourist village run without any further guidance. Regional Tourism Department must provide a proper guidance so that the tourist village can be continuously developed. Regional Tourism Department may request advices from Regional Tourism Promotion Agency. As partner of regional government, this Regional Tourism Promotion Agency has an obligation to submit advices to regional government because this agency knows more about what is needed by the tourism market. Besides that, this agency can also provide guidance to the tourist village based on the need of tourism market. Because this agency that is in charge to promote the tourist village as a form of Community Based Tourism. From the cooperation pattern above, it also can be seen that the success of tourist village is influenced by an active coordination between community as the tourist village manager with Regional Tourist Department and Regional Tourism Promotion Agency including in terms of decision making. Because beside role of regional government, an active community participation will also determine success development of tourist village. A professional management can improve the welfare of community who lives in tourist village.

For the eight tourist villages which is categorized as undeveloped in Badung Regency, Regional Tourism Department must conduct a proper guidance and supervision through education such as; conducting training to the human resources as the manager of tourist village, hotels and existed tourism schools. Regional Government can also conduct monitoring and evaluation to the tourist village management system. And another important thing, Regional Government need to make a correction by improving the facilities and infrastructures of tourist attraction so that the eight tourist village can be developed as good as the three other. A synergistic partners between Regional Tourism Department and Regional Tourism Promotion Agency can be achieved through establish a good partnership with other stakeholders/industries such as ASITA, PHI and other travel agency to schedule a visit to the tourist villages.

\section{CONCLUSIONS AND SUGGESTION}

Regarding the regional autonomy, the task of Regional Government is to conduct the development and construction in tourist village based on Community Based Development concept. Based on the condition of several tourist village which still undeveloped in Badung regency, it is confirmed that the role of Regional Tourism Department is not only as a policy maker but also need to conduct supervision and guidance through education and improving facilities and infrastructures in order to support development of Community Based Tourism concept. In line with that, Regional Tourism Department need to establish a synergistic relationship with Regional Tourism Promotion Agency as a partner. Role of Regional Tourism Promotion Agency as partner for regional government is as the policy implementer beside submitting advice and providing guidance to tourist village by involving other stake holders/industry. Community as the manager of tourist village need to be proactive to coordinate with Regional Tourism Department and Regional Tourism Promotion Agency. Therefore, in order to achieve the sustainability of tourist village as one form of Community Based Tourism, there must be a synergistic relationship between Regional Tourism Department, Regional Tourism Promotion Agency and Tourist Village. In this current situation, Regional Government must focus on conducting their role and give full attention to the undeveloped eight tourist villages before establishing another new tourist village. There must be a facts of integrity from community so that funds that is delivered will not be wasted and the most important thing is to create the tourism development that can support community welfare improvement.

\section{REFERENCES}

[1] Yoeti, A, Oka, Pengantar Ilmu Pariwisata, 1996, Angkasa, Bandung, Cetakan Pertama

[2] Ditjen Pariwisata, 1985, Pengantar Pariwisata Indonesia, Jakarta, Direktorat Jendral Pariwisata,

[3] Adirozal, Zulkarnain Harun Jurnal Antropologi, Tahun IV No 6, JuliDesember 2002

[4] Pitana, I Gde \& Putu G Gayatri. 2005. Sosiologi Pariwisata. Andi: Yogyakarta

[5] Anonim.2012, Profil Dinas Pariwisata Kabupaten Badung Tahun 2012, Badung, Pusat PemerintahanMangupraja

[6] Amiruddin dan Zainal Asikin, 2004, Pengantar Metode Penelitian Hukum, PT. Raja Grafindo Persada, Jakarta.

[7] Bagyono, 2005, Pariwisata dan Perhotelan, Alfabeta, Bandung

[8] Ni Ketut Bagiastuti, 2011, Wewenang Pemerintah Daerah Dalam Pembentukan Badan Promosi Pariwisata Daerah Provinsi Bali, Tesis, Udayana, Bali

[9] Hadiwijoyo, Suryo S. 2012. Perencanaan Pariwisata Perdesaan Berbasis Masyarakat; Sebuah Pendekatan Konsep,Yogyakarta :Graha Ilmu. 
[10] Ni Nyoman Ayu Hari Nalayani, 2012, Evaluasi Dan Stategi Pengembangan Desa Wisata Di Kabupaten Badung, Bali,Tesis, Universitas Udayana.

[11] Nuryanti, Wiendu. 1993. "Concept, Perspective and Challenges". Makalah bagian dari Laporan Konferensi Internasional mengenai Pariwisata Budaya di Yogyakarta.

[12] Mangupura, Denpost 20/04/2016 Undang-Undang No.32 Tahun 2004 tentang Pemerintah Daerah.

[13] Undang-Undang No. 10 Tahun 2009 tentang Kepariwisataan.

[14] Peraturan Gubernur Bali No 51 Tahun 2008 tentang Tugas Pokok Dinas Pariwisata.

[15] Peraturan Bupati Badung Nomor 47 Tahun 2010 tentang Penetapan Kawasan Desa Wisata di Kabupaten Badung.

[16] http://www.kompasiana.com/alexandersirait/menyelesaikanhambatan-untuk-wujudkan-mimpi-sektor-pariwisata-sebagai-sektorunggulan-menjadi-enyataan_566113334ef9fd7e050d09e6
[17] http://adeulfa-regulera.blogspot.co.id/

[18] http://www.parekraf.go.id/userfiles/file/4636_1364UUTentangKep ariwisataannet1.pdf.

[19] http://perencanaankota.blogspot.com/2012/01/dampakpembangunan-pariwisata-hasil.html.

[20] http://www.slideshare.net/Rafaellamadea/peranan-pariwisata-dalambidang-sosialekonomi-modul-2.

[21] http://www.budpar.go.id, Rencana Strategis Kementerian Kebudayaan dan Pariwisata Tahun 2010 - 2014.

[22] http://www.pewarta-kabarindonesia.blogspot.com Alamat ratron (surat elektronik): redaksi@kabarindonesia.com Berita besar hari ini...!!! Kunjungi segera: www.kabarindonesia.com 